Abstract

\title{
Assessment of Population Growth of Rhopalosiphum padi L. Aphids on the Seedlings of Selected Maize Cultivars ${ }^{\dagger}$
}

\author{
Julia Sławianowska and Hubert Sytykiewicz *
}

Citation: Sławianowska, J.; Sytykiewicz, H. Assessment of Population Growth of Rhopalosiphum padi L. Aphids on the Seedlings of Selected Maize Cultivars, in Proceedings of the 1st International Electronic Conference on Entomology, 1-15 July 2021, MDPI: Basel, Switzerland, doi:10.3390/IECE10513

Published: 1 July 2021

Publisher's Note: MDPI stays neutral with regard to jurisdictional claims in published maps and institutional affiliations.

Copyright: (C) 2021 by the authors. Submitted for possible open access publication under the terms and conditions of the Creative Commons Attribution (CC BY) license (http://creativecommons.org/licenses /by/4.0/).
Institute of Biological Sciences, Faculty of Exact and Natural Sciences, Siedlce University of Natural Sciences and Humanities, 14 Prusa St., 08-110 Siedlce, Poland

* Correspondence: huberts@uph.edu.pl

† Presented at the 1st International Electronic Conference on Entomology (IECE 2021), 1-15 July 2021; Available online: https://iece.sciforum.net/.

\begin{abstract}
Maize (Zea mays L.) is one of the most economically important cereal species. However, climate change and anthropogenic factors may contribute to increased susceptibility to a wide variety of pests, resulting in significant yield losses. At present, maize breeding is directed towards the search for hybrid varieties exhibiting increased resistance to unfavorable environmental factors. The aim of this study was to assess the susceptibility of seedlings of four selected maize cultivars to infestation by wingless females of the bird cherry-oat aphid (Rhopalosiphum padi L.). The biotests were carried out on 14-day-old maize seedlings (Nimba, Kanonier, Podium and Prezent cultivars) under controlled conditions in the environmental chamber. Population size and its structure as well as feeding site preferences of wingless females of $R$. padi on the tested maize seedlings were determined. Two levels of aphid colonization of the host plants (initially 5 and 50 aphids per seedling) and two periods of insect feeding ( 5 and 10 days) were tested. So far, there are no available reports on the interaction between the examined maize varieties and the bird cherry-oat aphid. The results of the experiments allowed to classify the Nimba cv. as susceptible, Kanonier and Podium cvs appeared to be moderately resistant, while Prezent cv. was highly resistant to the examined insects. The aphid populations reached higher numbers on susceptible Nimba seedlings in comparison to more resistant cultivars, and this effect was dependent on the initial level of aphid colonization. In addition, the larvae were predominant in the population structure of $R$. padi on seedlings of all the tested maize cultivars. On the other hand, higher number of adult females were found on Nimba plants, compared to the resistant varieties. Furthermore, it has been revealed plasticity of feeding site preferences of $R$. padi aphids when feeding on the seedlings of the investigated maize cultivars.
\end{abstract}

Keywords: Maize; Rhopalosiphum padi; feeding; infestation 